University of Nebraska - Lincoln

DigitalCommons@University of Nebraska - Lincoln

Faculty Publications: Department of

Entomology

Entomology, Department of

2008

\title{
Use of Spectral Vegetation Indices Derived from Airborne Hyperspectral Imagery for Detection of European Corn Borer Infestation in lowa Corn Plots
}

\author{
Matthew W. Carroll \\ United States Environmental Protection Agency, carroll.matthew@epa.gov \\ John A. Glaser \\ United States Enviromental Protection Agency \\ Richard L. Hellmich \\ USDA-ARS \\ Thomas E. Hunt \\ University of Nebraska-Lincoln, thunt2@unl.edu \\ Thomas W. Sappington \\ USDA-ARS, tsapping@iastate.edu \\ See next page for additional authors \\ Follow this and additional works at: https://digitalcommons.unl.edu/entomologyfacpub \\ Part of the Entomology Commons
}

Carroll, Matthew W.; Glaser, John A.; Hellmich, Richard L.; Hunt, Thomas E.; Sappington, Thomas W.; Calvin, Dennis; Copenhaver, Ken; and Fridgen, Jon, "Use of Spectral Vegetation Indices Derived from Airborne Hyperspectral Imagery for Detection of European Corn Borer Infestation in lowa Corn Plots" (2008). Faculty Publications: Department of Entomology. 299.

https://digitalcommons.unl.edu/entomologyfacpub/299

This Article is brought to you for free and open access by the Entomology, Department of at DigitalCommons@University of Nebraska - Lincoln. It has been accepted for inclusion in Faculty Publications: Department of Entomology by an authorized administrator of DigitalCommons@University of Nebraska - Lincoln. 


\section{Authors}

Matthew W. Carroll, John A. Glaser, Richard L. Hellmich, Thomas E. Hunt, Thomas W. Sappington, Dennis Calvin, Ken Copenhaver, and Jon Fridgen 


\title{
Use of Spectral Vegetation Indices Derived from Airborne Hyperspectral Imagery for Detection of European Corn Borer Infestation in Iowa Corn Plots
}

\author{
MATTHEW W. CARROLL, ${ }^{1,2}$ JOHN A. GLASER, ${ }^{1}$ RICHARD L. HELLMICH, ${ }^{3}$ THOMAS E. HUNT, ${ }^{4}$ \\ THOMAS W. SAPPINGTON, ${ }^{3}$ DENNIS CALVIN,${ }^{5}$ KEN COPENHAVER, $^{6}$ AND JOHN FRIDGEN ${ }^{6}$
}

\section{J. Econ. Entomol. 101(5): 1614-1623 (2008)}

\begin{abstract}
Eleven spectral vegetation indices that emphasize foliar plant pigments were calculated using airborne hyperspectral imagery and evaluated in 2004 and 2005 for their ability to detect experimental plots of corn manually inoculated with Ostrinia nubilalis (Hübner) neonate larvae. Manual inoculations were timed to simulate infestation of corn, Zea mays L., by first and second flights of adult $O$. nubilalis. The ability of spectral vegetation indices to detect $O$. nubilalis-inoculated plots improved as the growing season progressed, with multiple spectral vegetation indices able to identify infested plots in late August and early September. Our findings also indicate that for detecting $O$. nubilalis-related plant stress in corn, spectral vegetation indices targeting carotenoid and anthocyanin pigments are not as effective as those targeting chlorophyll. Analysis of image data suggests that feeding and stem boring by $O$. nubilalis larvae may increase the rate of plant senescence causing detectable differences in plant biomass and vigor when compared with control plots. Further, we identified an approximate time frame of 5-6 wk postinoculation, when spectral differences of manually inoculated "second" generation $O$. nubilalis plots seem to peak.
\end{abstract}

KEY WORDS Bt corn, remote sensing, Ostrinia nubilalis, European corn borer, resistance

In 2006, field corn, Zea mays L., grown for grain was harvested from $>28$ million ha in the United States and had a production value of $>\$ 33$ billion (NASS $2007 a, b)$. One of the most serious pests to corn production in North America is the European corn borer, Ostrinia nubilalis (Hübner). O. nubilalis is present throughout the major corn-producing areas in the United States, and it is capable of significantly reducing corn yield if not controlled (Ostlie et al. 1997). $O$. nubilalis is capable of multiple generations per year and in states like Iowa, the O. nubilalis ecotype is bivoltine, with two distinct moth flights each of 4-6-wk duration (Showers et al. 1975).

Transgenic corn expressing the insecticidal plant incorporated protectant (PIP) Bacillus thuringiensis (Bt) toxin was commercially released for $O$. nubilalis control in 1996 and accounted for $40 \%$ of all U.S. corn

\footnotetext{
${ }^{1}$ United States Environmental Protection Agency, Office of Research and Development, 26 W. Martin Luther King Dr., Cincinnati, $\mathrm{OH} 45268$.

${ }^{2}$ Corresponding author, e-mail: carroll.matthew@epa.gov.

${ }^{3}$ USDA-ARS, Corn Insects and Crop Genetics Research Unit, and Department of Entomology, Iowa State University, 102 Genetics Laboratory, Ames, IA 50011.

${ }^{4}$ Haskell Agricultural Laboratory, 57905866 Rd., Concord, NE 68728 .

${ }^{5}$ The Pennsylvania State University, 229C Ag Administration Bldg., University Park, PA 16802

${ }^{6}$ Institute for Technology Development, 1401 Regency Dr. East Suite B, Savoy, IL 61874
}

planted in 2006 (NASS 2007b). Transgenic corn hybrids currently available to growers contain multiple traits (stacks), including Bt for corn borer [O. nubilalis and Diatraea grandiosella (Dyar) control], Bt for corn rootworm (Diabrotica virgifera virgifera LeConte and Diabrotica barberi Smith \& Lawrence) control and herbicide tolerance. The U.S. Environmental Protection Agency (U.S. EPA) registers all PIP-expressing plants under the Federal Insecticide Fungicide and Rodenticide Act and has determined that crops containing insecticidal PIP traits are beneficial to the public because of their potential to increase yields with fewer applications of insecticides (U.S. EPA 2001, Hunt et al. 2007). However, widespread use of these crops increases risk of corn insect pests developing resistance to Bt toxins. Loss of Bt trait effectiveness due to insect resistance would increase grower reliance on broad-spectrum chemical insecticides that would, in turn, reduce environmental quality, and increase worker exposure to hazardous chemicals.

To minimize potential for development of insect resistance to Bt corn, U.S. EPA mandates a high-dose/ refuge insect resistance management (IRM) strategy for $O$. nubilalis. This management tactic is based on the assumptions that plants are expressing Bt toxin at levels sufficient to ensure that resistance is functionally recessive and any potentially resistant $O$. nubilalis are most likely to mate with susceptible moths emerg- 
ing from non-Bt corn refuge (Tabashnik and Croft 1982; Alstad and Andow 1995, 1996; Roush 1997; Gould 1998). Depending on regional crop composition, U.S. EPA requires that growers plant 20 to $50 \%$ of their acreage to non-Bt corn hybrids to ensure adequate production of susceptible moths. Additionally, U.S. EPA requirements for PIP crop registration include stewardship responsibilities, such as crop monitoring for insect pest resistance. However, a national monitoring program designed to detect early development of $O$. nubilalis resistance to Bt corn by using traditional sampling methods requires physically sampling cornfields on a geographic scale that would be logistically impractical and expensive to implement.

Remote sensing provides a means of reliably locating corn plantings in the landscape and detecting crop plant stress (Bauer et al. 1979, Bauer 1985, Curran 1985, Lichtenthaler et al. 1998, Zhao et al. 2005, Tilling et al. 2007). It potentially could improve upon current ground-based techniques for monitoring $O$. nubilalis in corn by providing spatially explicit information on the entire field that can be integrated with existing $O$. nubilalis sampling methodology. Additionally, the flexibility offered by numerous aerial and satellite platforms allows remote-sensed imagery at different spectral and spatial resolutions to be acquired nearly simultaneously over time (Cihlar et al. 1991). Consequently, the areal scalability and spatial context of remote-sensed imagery would address many logistical issues facing a national monitoring program for $O$. nubilalis in field corn. Imagery acquired by satellites at regional scales would allow discrimination of corn from other crops in the landscape, whereas higher resolution airborne hyperspectral images would allow evaluation of individual corn fields for hybrid type and insect-related plant stress.

Hyperspectral sensors, sometimes referred to as imaging spectrometers, provide a high degree of spectral resolution compared with multispectral imagery by taking nearly continuous measurements over the visible, near infrared (IR) / middle IR regions of the spectrum at narrow intervals. The increased sensitivity provided by the spectral resolution of hyperspectral imagery allows unique spectral features associated with crop condition to be identified (Thenkabail et al. 2000, Govender et al. 2007). However, the improved spectral resolution of hyperspectral imagery significantly increases image dimensionality, data redundancy, and file size. Spectral vegetation indices (SVI), such as the normalized difference vegetation index (NDVI) (Rouse et al. 1974, Tucker 1979), provide one method of reducing multidimensional data acquired from multiband or hyperspectral imagery to a single value that can be used to qualitatively and quantitatively assess various crop vegetation parameters while maintaining unique spectral information (Perry and Lautenschlager 1984, Apan et al. 2004).

Conceptually, use of remote sensing to indirectly evaluate crop condition is not new and benefits of early detection of crop stress are obvious but examples of its practical employment are limited. However, the increasing number of ground, aerial and satellite based sensors available for use, improved spatial and spectral resolution of current sensors and integration of accurate spatial information through global positioning system (GPS) is making remote sensing more applicable to agricultural science. Use of remote sensing to assess crop parameters, such as nitrogen, iron, and phosphorous status (Daughtry et al. 2000, Osborne et al. 2002, Zhao et al. 2003, Schlemmer et al. 2005), and biophysical information, such as leaf area index (LAI) and yield (Thenkabail et al. 2000, Calera et al. 2004, Haboudane et al. 2004, Vina et al. 2004), are becoming more common. Remote sensing also has been used in agricultural insect pest management. Recent examples include use of remotely sensed imagery to examine crop-insect interactions at local and regional scales (Brewster et al. 1999, Grilli 2006), investigate feeding damage to winter wheat, by greenbug (Mirik et al. 2006), detect cotton aphid and spider mite damage to cotton (Fitzgerald et al. 2004, Reisig and Godfrey 2006), examine chlorophyll loss from soybean aphid feeding on soybean (Diaz-Montano et al. 2007), characterize reflectance spectra of wheat infested with Russian wheat aphid and greenbug (Riedell and Blackmer 1999) and detect phylloxera-infested grape vines (Blanchfield et al. 2006). Much of this research was conducted using spectroradiometers with small fields of view (FOV) of less than a meter or used satellite imagery with coarse spatial resolutions, both of which can limit their usefulness for insect pest management in production agriculture. However, these studies demonstrate the feasibility of using spectral detection methods for identification of insect related plant stress.

Use of spectral information as an indicator of plant stress requires an alteration of the plants reflectance characteristics in visible light between 380- and 700 -nm wavelengths and in the infrared at wavelengths between 700 and $2500 \mathrm{~nm}$ (Carter 1993). Physical invasion of corn stalks by $O$. nubilalis larvae disrupts nutrient and water translocation within the corn plant, increases incidence of stem rot diseases, such as anthracnose (Bergstrom and Nicholson 1999), and can induce early senescence. Disruption of water and nutrient translocation influences plant pigment dynamics and is well correlated with a plant's physiological condition (Blackburn 2007). Leaf water content influences light absorption by determining how light interacts with wavelength independent factors, such as internal leaf structures that are defined by the type and number of cells present, and their distribution, shape, and ultrastructure (Woolley 1971, Gausman 1977, Carter 1991). Changes in reflectance from disruption of water translocation are caused by increased numbers of interfaces between wet cells and intercellular air spaces that develop as water is lost from plant tissues (Gausman and Cardenas 1969, Knipling 1970, Woolley 1971, Carter 1991). Typically, leaf water content in most plants influences light reflectance at wavelengths $>1,000 \mathrm{~nm}$ (Carter 1991, Broge and Leblanc 2000), but as Woolley (1971) cautioned when explaining the influence of leaf water content on light reflectance for soybean, Glycine $\max (\mathrm{L}$.) Merr., and 
corn leaves, the amount of change observed in the intercellular spaces may depend on differences in mesophyll (i.e., monocots and dicots) and photosynthetic capacity. $O$. nubilalis larvae feeding within the plant stem should affect adaxial and abaxial surface reflectance between $400 \mathrm{~nm}$ and 2,500 $\mathrm{nm}$ as a result of decreased water content in plant tissues (Woolley 1971, Carter 1991) and be detectable by a hyperspectral sensor. Additionally, yellowing and other visible color changes associated with stressed or senescing leaf tissue that results from chlorophyll degradation unmasking secondary pigments such as carotenoids and anthocyanins (Matile and Hortensteiner 1999) also may be detectable.

The objective of this study was to determine whether spectral vegetation indices using wavelengths sensitive to the plant pigments chlorophyll, anthocyanin, and carotenoids, are able to distinguish corn plots manually inoculated with $O$. nubilalis from noninoculated control plots of corn. We discuss use of pigment-based indices and their potential role in monitoring for O. nubilalis resistance to $\mathrm{Bt}$ corn.

\section{Materials and Methods}

Experimental Plots. Experimental corn plots were planted southwest of Ames, IA, on the Bennett farm in 2004 and Been farm in 2005 by using standard grower practices for corn production. Nitrogen applied at 157 $\mathrm{kg} / \mathrm{ha}$ in liquid $32 \%$ form was tank mixed with the herbicide Acetochlor (2-chloro- $N$ (ethoxymethyl) - 6 'ethyl-o-acetotoluidide) and applied to all plots in 2004 and 2005 before plant emergence. A postemergence herbicide, Diglycolamine salt (3,6-dichloro-o-anisic acid) was applied later in the season. Row spacing for all plots in 2004 and 2005 was $76.2-$ at $19.1-\mathrm{cm}$ plant spacing. Individual plots were $4.6 \mathrm{~m}$ (four rows) by $18.3 \mathrm{~m}$ in 2004 but were increased to $9.1 \mathrm{~m}$ (12 rows) by $18.3 \mathrm{~m}$ in 2005 to increase the number of picture elements (pixels) available for image analysis. Inoculation treatments were randomly assigned to plots of DeKalb DKC57-01 field corn by using a randomized block design replicated five times in 2004 and 2005.

Inoculation of Corn Plants with $\boldsymbol{O}$. nubilalis. Plants were inoculated with $O$. nubilalis neonates (Guthrie and Barry 1988) during V8-V10 growth stages on 24 and 25 June 2004 and 22 and 24 June 2005 to simulate first generation $O$. nubilalis and during R1, or R2 growth stages on 27 and 28 July 2004 and 22 July 2005 to simulate second generation O. nubilalis (Ritchie et al. 1997). In 2004, three treatments were established using $50 \mathrm{O}$. nubilalis neonates per plant for first generation, 50 neonates per plant for second generation, and plots with no inoculation to serve as a control. In 2005 , an additional $O$. nubilalis density of 25 neonates every second plant, categorized as low, was added to second generation $O$. nubilalis treatments. Four and eight middle rows of treated plots were inoculated in 2004 and 2005, respectively.

Damage Assessment. Foliar feeding by first generation $O$. nubilalis larvae was evaluated using the Guthrie rating scale on 8 July 2004 when plants were at
V12-V13 growth stage and 7 and 8 July 2005 at the V9-V11 growth stage. The mean Guthrie rating for 10 total plants was calculated for each plot by arbitrarily selecting five consecutive plants from each of the two center rows and visually assessing leaf feeding on a 1-9 scale where one is no damage and nine is extensive damage (Guthrie and Barry 1988). Stalk tunneling damage by $O$. nubilalis was assessed at the end of the growing season in 2004 and 2005 by arbitrarily selecting five consecutive plants from each of the two center rows for dissection. Plants were dissected by vertically splitting each stem along the length of the stalk with a hawk billed grafting knife (pruner \#1B, Camillus Cutlery. Camillus, NY). Plants were individually evaluated for damage from $O$. nubilalis tunneling by enumerating number of entrance holes resulting in a tunnel $>1 \mathrm{~cm}$. Total number of cavities per plant were recorded and converted to mean number of cavities per 10 plants for a given treatment.

Hyperspectral Remote Sensing. Hyperspectral images of the experimental plots were acquired at $0.5-\mathrm{m}$ resolution by using a real-time data acquisition camera system-hyperspectral (RDACS-H4) airborne camera system modified by ITD (Institute of Technology and Development, Savoy, IL) mounted on a Zeiss T-Al gyro-stabilized suspension system (Intergraph, Huntsville, AL) in a Cessna 210 single engine fixed wing aircraft. Plots were imaged six times in 2004 on 12 July, 25 July, 9 August, 20 August, and 3 September and 17 September and five times in 2005 on 1 August, 17 August, 30 August, 10 September, and 26 September. Spectral resolution of images consisted of 120 spectral bands between 473 and $827 \mathrm{~nm}$ at $0.5-\mathrm{m}^{2}$ spatial resolution for 2004 and 240 bands from 400 to $1000 \mathrm{~nm}$ at $0.5 \mathrm{~m}^{2}$ for 2005 .

Before analysis hyperspectral imagery was preprocessed to remove signal noise, calibrated to relative reflectance, and then straightened and spatially registered to a real-world coordinate system. Preprocessing was accomplished using ENVI 4.0 (ITT Visual Information Solutions, Boulder, CO) to remove electronic noise by means of a minimum noise fraction (MNF) rotation. The MNF procedure uses both raw hyperspectral and dark current image data as inputs to an algorithm similar to principal components analysis to perform a two cascaded transformation on image data to isolate signal noise.

Calibration of hyperspectral imagery to relative reflectance was achieved using the following methods. Seven $4.57-\mathrm{m}^{2}$ gray scaled (black to white) calibration tarps that varied in percent of reflectance from 2 to $83 \pm 1 \%$ were placed adjacent to the experimental area. A GER 1500 spectroradiometer with a spectral range of 350-1,050 $\mathrm{nm}$ at 1.5-nm bandwidth (Geophysical Environmental Research Corp., Millbrook, NY) was used to acquire four scans over quadrants of each tarp as close to the time of image acquisition as was possible. After acquiring plot images, the empirical line method (Smith and Milton 1999) in ENVI 4.0 was used to develop an equation for the relationship between digital numbers recorded by the sensor for 
Table 1. Spectral vegetation indices used to differentiate 2004 and 2005 Iowa corn plots manually inoculated with $O$. nubilalis neonate larvae

\begin{tabular}{|c|c|c|c|}
\hline Index & Abbreviation & Equation & Source \\
\hline $\begin{array}{l}\text { Normalized difference } \\
\text { vegetation index }\end{array}$ & NDVI & $\frac{\mathrm{R}_{800}-\mathrm{R}_{670}}{\mathrm{R}_{800}+\mathrm{R}_{670}}$ & Rouse et al. (1974) \\
\hline Red edge position & Red edge & $\frac{\mathrm{R}_{670}+\mathrm{R}_{780}}{2}$ & Guyot and Baret (1988) \\
\hline $\begin{array}{l}\text { Pigment specific simple ratio for } \\
\text { chlorophyll a }\end{array}$ & $\mathrm{PSSR}_{\mathrm{a}}$ & $\frac{\mathrm{R}_{800}}{\mathrm{R}_{680}}$ & Blackburn (1998) \\
\hline $\begin{array}{l}\text { Pigment specific simple ratio for } \\
\text { chlorophyll b }\end{array}$ & $\mathrm{PSSR}_{\mathrm{b}}$ & $\frac{\mathrm{R}_{800}}{\mathrm{R}_{635}}$ & Blackburn (1998) \\
\hline $\begin{array}{l}\text { Modified chlorophyll absorption } \\
\text { ratio index }\end{array}$ & MCARI & $\left(\left(\mathrm{R}_{700}-\mathrm{R}_{670}\right)-0.2 *\left(\mathrm{R}_{700}-\mathrm{R}_{550}\right)\right) *\left(\frac{\mathrm{R}_{700}}{\mathrm{R}_{670}}\right)$ & Daughtry et al. (2000) \\
\hline \multirow[t]{2}{*}{ MCARI/OSAVI ratio } & MOSR & $\left(\left(\mathrm{R}_{700}-\mathbf{R}_{670}\right)-0.2 *\left(\mathrm{R}_{700}-\mathbf{R}_{550}\right)\right) *\left(\frac{\mathrm{R}_{700}}{\mathbf{R}_{670}}\right)$ & Haboudane et al. (2002) \\
\hline & & $\frac{\left(\left(\mathbf{R}_{800}-\mathbf{R}_{670}\right)-1\right)}{\left(\left(\sqrt{\mathbf{R}_{800}+\mathbf{R}_{670}}\right)+1\right)}$ & \\
\hline $\begin{array}{l}\text { Anthocyanin reflectance index } \\
\text { (ARI) }\end{array}$ & ARI & $\left(\mathbf{R}_{561}^{-1}-\mathbf{R}_{706}^{-1}\right) * \mathbf{R}_{780}$ & Gitelson and Merzlyak (2004) \\
\hline $\begin{array}{l}\text { Carotenoid reflectance index, } \\
\text { green wavelength }\end{array}$ & $\mathrm{CRI}_{\text {green }}$ & $\left(\mathbf{R}_{510}^{-1}-\mathbf{R}_{561}^{-1}\right) * \mathbf{R}_{780}$ & Gitelson and Merzlyak (2004) \\
\hline $\begin{array}{l}\text { Carotenoid reflectance index, } \\
\text { red wavelength }\end{array}$ & $\mathrm{CRI}_{\text {red }}$ & $\left(\mathbf{R}_{510}^{-1}-\mathbf{R}_{706}^{-1}\right) * \mathbf{R}_{780}$ & Gitelson and Merzlyak (2004) \\
\hline Green model & GM & $\left(\frac{\mathrm{R}_{747}}{\mathrm{R}_{549}}\right)-1$ & Gitelson et al. (2005) \\
\hline Red model & $\mathrm{RM}$ & $\left(\frac{\mathrm{R}_{747}}{\mathrm{R}_{-0}}\right)-1$ & Gitelson et al. (2005) \\
\hline
\end{tabular}

the calibration tarp and the "true" reflectance values from spectroradiometer scans.

Before spatial registration of the imagery, a spatial reference grid for the experimental plots was created by placing 30 white painted $0.25-\mathrm{m}^{2}$ wooden panels midway between plots and at plot corners along the exterior. Panels were georeferenced to centimeter accuracy using a Trimble Pathfinder ProXRS GPS unit (Trimble Navigation Limited, Sunnyvale, CA) and digitally stored for later use.

Spatial registration of acquired images to real world coordinates was accomplished using two methods. Preliminary image rectification was conducted using HYPER, a proprietary program developed by Institute for Technology Development (ITD) (Stennis Space Center, MS) that removes roll distortion in the imagery caused by aircraft roll motion. Imagery was georectified using ERDAS Imagine 8.7 (Leica Geosystems Geospatial Imaging, LLC, Norcross, GA). Additionally, hyperspectral imagery needed to be subset so that pixels with mixed reflectance from between plots and bordering areas would be excluded. Polygon shapefiles were created for each plot and used to define individual plot areas for export. Each hyperspectral image was converted from image space to ASCII format by using ERDAS Imagine's convert pixel to ASCII utility.

Eleven SVI that target plant pigments were selected for evaluation in this study (Table 1) and were considered a representative subset of many SVI currently available. Calculations for individual SVI (Table 1) were performed in SAS by using the 2004 and 2005 exported hyperspectral imagery data of the Iowa experimental plots. In 2005, some wavelengths used in
SVI calculations differed from those used in 2004 by 1 to $2 \mathrm{~nm}$ due to the increased spectral resolution of the 2005 imagery, but this difference was considered negligible.

Analyses. All data sets were checked for normality and homogeneity of variance using residual and normality plots before conducting analyses of variance (ANOVA). In cases where assumptions were not met, a $\log (y+c)$, square $\operatorname{root}(y+c)$ or $y^{2}$ transformation was sufficient to correct the issue, where c represents a constant added to change values of $y$ from negative to positive.

O. nubilalis damage levels in the plots were checked to determine whether differences between inoculation treatments were achieved. Mean Guthrie ratings and mean number of $O$. nubilalis cavities per plant were compared using a single factor ANOVA, Proc Mixed of SAS 9.1.3 (SAS Institute, Cary, NC), at the 0.05 level of significance. A multiple comparison between 2005 second generation O. nubilalis high- and low-inoculated treatments and noninoculated controls for mean number of $O$. nubilalis cavities per plant was performed using the Tukey-Kramer method for multiple comparisons $(\alpha=0.05)$.

Comparison of mean spectral vegetation indices per treatment for 2004 and 2005 first and second generation infestations were analyzed with repeated measures ANOVA (Proc Mixed SAS 9.1.3) by using calendar day of image acquisition to represent time beginning at the first imaging date after inoculation. The default variance-component covariate structure used by Proc Mixed (SAS 9.1.3) for analysis of timeseries data were not appropriate for imaging events 
Table 2. Mean number of $O$. nubilalis cavities per 10 plants from 2004 and 2005 Iowa corn plots manually inoculated with $O$. nubilalis neonate larvae

\begin{tabular}{|c|c|c|c|c|c|}
\hline Yr & $\begin{array}{l}\text { O. nubilalis } \\
\text { generation }\end{array}$ & Treatment & Inoculation rate & $\begin{array}{c}\text { Mean Guthrie } \\
\text { rating } \pm \mathrm{SE}\end{array}$ & $\begin{array}{c}\text { Mean no. } \\
\text { cavities } \pm \mathrm{SE}^{a}\end{array}$ \\
\hline 2004 & First & Control & 0 & $1.66 \pm 0.16 a$ & $0.02 \pm 0.004 a$ \\
\hline 2004 & First & High & 50 neonates/plant & $3.48 \pm 0.17 \mathrm{~b}$ & $0.08 \pm 0.02 \mathrm{~b}$ \\
\hline 2004 & Second & Control & 0 & & $0.02 \pm 0.004 \mathrm{a}$ \\
\hline 2004 & Second & High & 50 neonates/plant & & $0.76 \pm 0.05 b$ \\
\hline 2005 & First & Control & 0 & $1.80 \pm 0.53 \mathrm{a}$ & $0.02 \pm 0.01 \mathrm{a}$ \\
\hline 2005 & First & High & 50 neonates/plant & $4.11 \pm 0.48 b$ & $0.09 \pm 0.03 \mathrm{a}$ \\
\hline 2005 & Second & Control & 0 & & $0.02 \pm 0.01 \mathrm{a}$ \\
\hline 2005 & Second & Low & 25 neonates every fourth plant & & $0.1 \pm 0.01 \mathrm{a}$ \\
\hline 2005 & Second & High & 50 neonates/plant & & $0.4 \pm 0.03 \mathrm{~b}$ \\
\hline
\end{tabular}

${ }^{a}$ Mean number of cavities per 10 plants with the same letter for each year and generation are not statistically different at 0.05 level of significance.

not equally spaced over time. However, temporal measurements, such as imaging events, can be treated as a one-dimensional spatial process. Consequently, the spherical (power) spatial covariate structure was used to model covariance between imaging events acquired at different times (Littell et al. 1996). When treatment-time interactions were significant, differences between mean SVI for $O$. nubilalis inoculated treatments and noninoculated controls were examined by date $(\alpha=0.05)$ by using least square means (LS-means) in Proc Mixed (SAS 9.1.3). For multiple comparisons, differences between mean SVI for different inoculated treatments and noninoculated controls were examined using the adjusted LS-means provided by the Tukey-Kramer method for multiple comparisons $(\alpha=0.05)$ in Proc Mixed (SAS 9.1.3).

\section{Results}

Mean Guthrie ratings were found to be significantly different between noninoculated controls and first generation O. nubilalis inoculated plots in 2004 ( $F=60.23$; $\mathrm{df}=1,4 ; P=0.001)$ and $2005(F=10.47$; $\mathrm{df}=1,4 ; P=$ 0.03) (Table 2). Significant differences also were found between mean number of $O$. nubilalis cavities per plant
(Table 2) for noninoculated controls and first $(F=16.71$; $\mathrm{df}=1,4 ; P=0.02)$ and second $(F=222.9 ; \mathrm{df}=1,4 ; P=$ 0.0001 ) generation $O$. nubilalis inoculated plots in 2004 however, cavity numbers for 2005 (Table 2) first generation $O$. nubilalis inoculated treatments were not significantly different from noninoculated controls $(F=5.43$ $\mathrm{df}=1,4 ; P=0.08)$. Main treatment effect on mean number of cavities per plant for 2005 second generation O. nubilalis inoculation was significant $(F=63.95$; $\mathrm{df}=$ $2,8 ; P<0.0001)$. However, only the high second generation $O$. nubilalis inoculation treatment was significantly different from low inoculation $(t=8.41$; df $=2$, $8 ; P<0.0001)$ and noninoculated controls $(t=10.76$; df $=2,8 ; P<0.0001)$ with no significant differences between low inoculation treatments and noninoculated controls $(t=2.35 ; \mathrm{df}=2,8 ; P=0.11)$ (Table 2). Overall, manual inoculation of corn plants with neonate $O . n u$ bilalis larvae to create plots with different levels of $O$. nubilalis feeding damage was successful.

Eleven SVI were individually evaluated during the growing season for their ability to detect plots of corn manually inoculated with O. nubilalis in 2004 and 2005. For 2004 first generation O. nubilalis inoculated treatments, no significant treatment main effects or time by treatment interactions were detected (Tables 3 and 4)

Table 3. Repeated measures analysis of variance of spectral vegetation indices derived from hyperspectral imagery of $O$. nubilalis first generation treated corn plots and noninoculated controls from 2004 and 2005 Iowa

\begin{tabular}{|c|c|c|c|c|c|c|c|c|c|c|c|c|}
\hline \multirow{3}{*}{ Index } & \multicolumn{6}{|c|}{2004 first generation $O$. nubilalis } & \multicolumn{6}{|c|}{2005 first generation O. nubilalis } \\
\hline & \multicolumn{2}{|c|}{$\begin{array}{l}\text { Treatment } \\
(\mathrm{df}=1,4)\end{array}$} & \multicolumn{2}{|c|}{$\begin{array}{c}\text { Time } \\
(\mathrm{df}=5,48)\end{array}$} & \multicolumn{2}{|c|}{$\begin{array}{c}\text { Treatment } \times \\
\text { time } \\
(\mathrm{df}=5,48)\end{array}$} & \multicolumn{2}{|c|}{$\begin{array}{l}\text { Treatment } \\
(\mathrm{df}=1,4)\end{array}$} & \multicolumn{2}{|c|}{$\begin{array}{c}\text { Time } \\
(\mathrm{df}=4,32)\end{array}$} & \multicolumn{2}{|c|}{$\begin{array}{c}\text { Treatment } \times \\
\text { time } \\
(\mathrm{df}=4,32)\end{array}$} \\
\hline & $F$ & $P$ & $F$ & $P$ & $F$ & $P$ & $F$ & $P$ & $F$ & $P$ & $F$ & $P$ \\
\hline ARI & 0.06 & 0.820 & 591.42 & $<0.0001$ & 1.39 & 0.2443 & 0.06 & 0.8253 & 830.35 & $<0.0001$ & 2.88 & 0.0381 \\
\hline $\mathrm{CRI}_{\text {green }}$ & 0.00 & 0.9708 & 330.08 & $<0.0001$ & 0.75 & 0.5893 & 7.99 & 0.0475 & 2550.95 & $<0.0001$ & 0.34 & 0.8466 \\
\hline $\mathrm{CRI}_{\text {red }}$ & 0.08 & 0.7895 & 316.95 & $<0.0001$ & 1.42 & 0.2346 & 3.53 & 0.1334 & 2233.18 & $<0.0001$ & 0.51 & 0.7314 \\
\hline GM & 0.05 & 0.8355 & 396.48 & $<0.0001$ & 1.24 & 0.3056 & 3.64 & 0.1289 & 3138.93 & $<0.0001$ & 2.35 & 0.0749 \\
\hline MCARI & 0.00 & 1.0000 & 338.41 & $<0.0001$ & 0.39 & 0.8560 & 0.29 & 0.6173 & 1815.26 & $<0.0001$ & 1.28 & 0.2972 \\
\hline MOSR & 0.01 & 0.9307 & 216.35 & $<0.0001$ & 0.28 & 0.9241 & 0.25 & 0.6435 & 1247.10 & $<0.0001$ & 1.02 & 0.4111 \\
\hline NDVI & 0.03 & 0.8639 & 668.96 & $<0.0001$ & 1.10 & 0.3752 & 4.94 & 0.0904 & 13738.0 & $<0.0001$ & 5.58 & 0.0016 \\
\hline $\operatorname{PSSR}_{\mathrm{a}}$ & 0.04 & 0.8564 & 488.93 & $<0.0001$ & 1.28 & 0.2895 & 4.63 & 0.0978 & 11143.6 & $<0.0001$ & 3.03 & 0.0317 \\
\hline $\operatorname{PSSR}_{\mathrm{b}}$ & 0.02 & 0.9023 & 521.79 & $<0.0001$ & 0.90 & 0.4875 & 4.38 & 0.1045 & 7548.76 & $<0.0001$ & 4.02 & 0.0094 \\
\hline Red edge & 0.28 & 0.6254 & 59.12 & $<0.0001$ & 1.13 & 0.3573 & 10.03 & 0.0339 & 162.42 & $<0.0001$ & 0.70 & 0.5998 \\
\hline $\mathrm{RM}$ & 0.04 & 0.8590 & 201.77 & $<0.0001$ & 1.12 & 0.3642 & 4.90 & 0.0912 & 5076.92 & $<0.0001$ & 2.81 & 0.0416 \\
\hline
\end{tabular}


Table 4. Mean spectral vegetation indices for $O$. nubilalis inoculation treatments and noninoculated control by time of image acquisition for first generation $O$. nubilalis inoculated treatments from 2004 Iowa

\begin{tabular}{|c|c|c|c|c|c|c|c|c|c|c|c|c|c|c|}
\hline Date & $\begin{array}{l}\text { Days after } \\
\text { treatment }\end{array}$ & $\begin{array}{l}\text { O. nubilalis } \\
\text { generation }\end{array}$ & $\begin{array}{c}\text { Inoculation } \\
\text { treatment }\end{array}$ & ARI & $\mathrm{CRI}_{\text {green }}$ & $\mathrm{CRI}_{\text {red }}$ & GM & MCARI & MOSR & NDVI & $\operatorname{PSSR}_{\mathrm{a}}$ & $\operatorname{PSSR}_{\mathrm{b}}$ & Red edge & $\mathrm{RM}$ \\
\hline \multirow[t]{2}{*}{12 July } & 17 & First & Control & $1.62 \mathrm{a}$ & $-0.90 \mathrm{a}$ & $1.70 \mathrm{a}$ & $2.21 \mathrm{a}$ & $6.58 \mathrm{a}$ & $6.81 \mathrm{a}$ & $0.73 \mathrm{a}$ & $1.87 \mathrm{a}$ & $2.53 \mathrm{a}$ & $2.99 \mathrm{a}$ & $1.04 \mathrm{a}$ \\
\hline & & & High & $1.67 \mathrm{a}$ & $-0.95 a$ & $1.73 \mathrm{a}$ & $2.26 \mathrm{a}$ & $6.69 \mathrm{a}$ & $6.90 \mathrm{a}$ & $0.74 a$ & $1.92 \mathrm{a}$ & $2.58 \mathrm{a}$ & $3.03 \mathrm{a}$ & $1.09 \mathrm{a}$ \\
\hline \multirow[t]{2}{*}{25 July } & 30 & First & Control & $1.25 \mathrm{a}$ & $-0.43 a$ & $1.52 \mathrm{a}$ & $1.90 \mathrm{a}$ & $5.78 \mathrm{a}$ & $6.21 \mathrm{a}$ & $0.68 \mathrm{a}$ & $1.66 \mathrm{a}$ & $2.07 \mathrm{a}$ & $3.17 \mathrm{a}$ & $0.97 \mathrm{a}$ \\
\hline & & & High & $1.23 \mathrm{a}$ & $-0.42 \mathrm{a}$ & $1.51 \mathrm{a}$ & $1.88 \mathrm{a}$ & $5.70 \mathrm{a}$ & $6.16 \mathrm{a}$ & $0.67 \mathrm{a}$ & $1.64 \mathrm{a}$ & $2.04 \mathrm{a}$ & $3.15 \mathrm{a}$ & $0.95 \mathrm{a}$ \\
\hline \multirow[t]{2}{*}{9 Aug. } & 45 & First & Control & $1.24 \mathrm{a}$ & $-0.52 \mathrm{a}$ & $1.49 \mathrm{a}$ & $1.88 \mathrm{a}$ & $6.04 \mathrm{a}$ & $6.48 \mathrm{a}$ & $0.67 \mathrm{a}$ & $1.61 \mathrm{a}$ & $2.13 \mathrm{a}$ & $3.10 \mathrm{a}$ & $0.91 \mathrm{a}$ \\
\hline & & & High & $1.23 \mathrm{a}$ & $-0.50 \mathrm{a}$ & $1.48 \mathrm{a}$ & $1.86 \mathrm{a}$ & $6.02 \mathrm{a}$ & $6.49 \mathrm{a}$ & $0.66 \mathrm{a}$ & $1.58 \mathrm{a}$ & $2.10 \mathrm{a}$ & $3.09 \mathrm{a}$ & $0.89 \mathrm{a}$ \\
\hline \multirow[t]{2}{*}{20 Aug. } & 56 & First & Control & $1.30 \mathrm{a}$ & $-0.69 a$ & $1.50 \mathrm{a}$ & $1.90 \mathrm{a}$ & $6.82 \mathrm{a}$ & $7.21 \mathrm{a}$ & $0.68 \mathrm{a}$ & $1.65 \mathrm{a}$ & $2.13 \mathrm{a}$ & $3.08 \mathrm{a}$ & $0.81 \mathrm{a}$ \\
\hline & & & High & $1.26 \mathrm{a}$ & $-0.65 a$ & $1.49 \mathrm{a}$ & $1.86 \mathrm{a}$ & $6.81 \mathrm{a}$ & $7.25 \mathrm{a}$ & $0.66 \mathrm{a}$ & $1.60 \mathrm{a}$ & $2.10 \mathrm{a}$ & $3.08 \mathrm{a}$ & $0.77 \mathrm{a}$ \\
\hline \multirow[t]{2}{*}{3 Sept. } & 70 & First & Control & $0.79 \mathrm{a}$ & $-0.15 a$ & $1.34 \mathrm{a}$ & $1.52 \mathrm{a}$ & $4.92 \mathrm{a}$ & $5.87 \mathrm{a}$ & $0.51 \mathrm{a}$ & $1.14 \mathrm{a}$ & $1.60 \mathrm{a}$ & $3.05 \mathrm{a}$ & $0.54 \mathrm{a}$ \\
\hline & & & High & $0.75 \mathrm{a}$ & $-0.15 \mathrm{a}$ & $1.32 \mathrm{a}$ & $1.49 \mathrm{a}$ & $4.85 \mathrm{a}$ & $5.83 \mathrm{a}$ & $0.50 \mathrm{a}$ & $1.11 \mathrm{a}$ & $1.57 \mathrm{a}$ & $3.02 \mathrm{a}$ & $0.52 \mathrm{a}$ \\
\hline \multirow[t]{3}{*}{17 Sept. } & 84 & First & Control & $0.32 \mathrm{a}$ & $0.07 \mathrm{a}$ & $1.20 \mathrm{a}$ & $1.18 \mathrm{a}$ & $2.57 \mathrm{a}$ & $4.19 \mathrm{a}$ & $0.27 \mathrm{a}$ & $0.56 \mathrm{a}$ & $0.79 \mathrm{a}$ & $2.92 \mathrm{a}$ & $0.21 \mathrm{a}$ \\
\hline & & & High & $0.33 \mathrm{a}$ & $0.06 \mathrm{a}$ & $1.20 \mathrm{a}$ & $1.19 \mathrm{a}$ & $2.63 \mathrm{a}$ & $4.22 \mathrm{a}$ & $0.28 \mathrm{a}$ & $0.57 \mathrm{a}$ & $0.81 \mathrm{a}$ & $2.90 \mathrm{a}$ & $0.22 \mathrm{a}$ \\
\hline & & \multicolumn{2}{|c|}{ SEM } & 0.04 & 0.05 & 0.02 & 0.03 & 0.15 & 0.13 & 0.02 & 0.04 & 0.04 & 0.02 & 0.04 \\
\hline
\end{tabular}

Mean SVI with the same letter within each date are not statistically different at 0.05 level of significance.

for any SVI. In 2005, the SVI CRI green $_{\text {, }}$ and Red Edge position index both had significant treatment main effects, but neither index had significant treatment by time interactions for first generation inoculation treatments (Table 3). Although most SVI for first generation treatments during 2005 did not have significant main effects several SVI, namely, ARI, NDVI, PSSR $\mathrm{PSSR}_{\mathrm{b}}$, and Red model had significant time by treatment interactions (Table 3). These indices were able to discriminate first generation inoculated plots from noninoculated controls with three of the SVI, PSSR $\mathrm{PSSR}_{\mathrm{b}}$ and Red model, able to distinguish between first generation $O$. nubilalis inoculated plots on two consecutive occasions (Table 5).

Plots inoculated with second generation $O$. nubilalis were detected by more SVI than those inoculated with first generation O. nubilalis neonates. In 2004, 10 of 11 SVI for second generation $O$. nubilalis inoculated plots had significant main treatment effects, and all had significant treatment by time interactions (Table 6). In contrast, six of 11 SVI had significant main effects in 2005 (Table 6), with five of the six having significant treatment by time interactions.
Further examination of the 2004 LS-means for SVI with significant main treatment effects and treatment by time interactions for second generation $O$. nubilalis inoculated plots (Table 7) shows that mean values of each SVI for control and treatment plots were similar in August, 12 and $23 \mathrm{~d}$ after inoculation treatments (DAT). By 3 September (37 DAT), mean SVI for control plots were consistently higher than inoculated plots. Similar trends were observed for 2005 LS-means for six SVI (CRI ${ }_{\text {green }}$, GM, NDVI, PSSR, PSSR $_{b}$, and $\mathrm{RM}$ ) with significant main treatment effects and significant treatment by time interactions (Table 8). Mean SVI for control plots and inoculated plots were not separable until 26 DAT when a significant difference was detected for RM between high infestation $O$. nubilalis treatments and low infestation and noninoculated controls. At 39 and 50 DAT, the six significant SVI showed similar tendencies, with higher mean index values associated with control plots, likely caused by greater plant vigor and biomass compared with inoculated plots. Significant differences between high $O$. nubilalis infestation treatments and low infestation and noninoculated controls were observed at 39 and

Table 5. Mean spectral vegetation indices for $O$. nubilalis inoculation treatments and noninoculated control by time of image acquisition for first generation $O$. nubilalis inoculated treatments from 2005 Iowa

\begin{tabular}{|c|c|c|c|c|c|c|c|c|c|c|c|c|c|c|}
\hline Date & $\begin{array}{l}\text { Days after } \\
\text { treatment }\end{array}$ & $\begin{array}{l}\text { O. nubilalis } \\
\text { generation }\end{array}$ & Treatment & ARI & $\mathrm{CRI}_{\text {green }}$ & $\mathrm{CRI}_{\text {red }}$ & GM & MCARI & MOSR & NDVI & $\operatorname{PSSR}_{\mathrm{a}}$ & $\mathrm{PSSR}_{\mathrm{b}}$ & Red edge & $\mathrm{RM}$ \\
\hline \multirow[t]{2}{*}{1 Aug. } & \multirow[t]{2}{*}{38} & \multirow[t]{2}{*}{ First } & Control & $1.69 \mathrm{a}$ & $1.27 \mathrm{a}$ & $1.68 \mathrm{a}$ & $1.70 \mathrm{a}$ & $1.84 \mathrm{a}$ & $2.90 \mathrm{a}$ & $0.73 a$ & $2.66 \mathrm{a}$ & $2.42 \mathrm{a}$ & $3.11 \mathrm{a}$ & $2.34 \mathrm{a}$ \\
\hline & & & High & $1.69 \mathrm{a}$ & $1.25 \mathrm{a}$ & $1.67 \mathrm{a}$ & $1.67 \mathrm{a}$ & $1.85 \mathrm{a}$ & $2.98 \mathrm{a}$ & $0.73 \mathrm{a}$ & $2.63 \mathrm{a}$ & $2.40 \mathrm{a}$ & $3.08 \mathrm{a}$ & $2.30 \mathrm{a}$ \\
\hline \multirow[t]{2}{*}{17 Aug. } & \multirow[t]{2}{*}{54} & \multirow[t]{2}{*}{ First } & Control & $1.64 \mathrm{a}$ & $1.55 \mathrm{a}$ & $1.96 \mathrm{a}$ & $1.60 \mathrm{a}^{a}$ & $1.95 \mathrm{a}$ & $3.62 \mathrm{a}$ & $0.74 a$ & $2.60 \mathrm{a}$ & $2.41 \mathrm{a}$ & $2.95 \mathrm{a}$ & $2.26 \mathrm{a}$ \\
\hline & & & High & $1.66 \mathrm{~b}$ & $1.52 \mathrm{a}$ & $1.95 \mathrm{a}$ & $1.56 \mathrm{a}^{a}$ & $1.96 \mathrm{a}$ & $3.80 \mathrm{a}$ & $0.73 \mathrm{a}$ & $2.54 \mathrm{~b}$ & $2.36 \mathrm{~b}$ & $2.91 \mathrm{a}$ & $2.19 b$ \\
\hline \multirow[t]{2}{*}{30 Aug. } & \multirow[t]{2}{*}{67} & \multirow[t]{2}{*}{ First } & Control & $1.93 \mathrm{a}$ & $0.51 \mathrm{a}^{b}$ & $1.35 \mathrm{a}^{c}$ & $1.39 \mathrm{a}$ & $1.96 \mathrm{a}$ & $4.38 \mathrm{a}$ & $0.55 \mathrm{a}$ & $1.85 \mathrm{a}$ & $1.89 \mathrm{a}$ & $2.86 \mathrm{a}$ & $1.63 \mathrm{a}$ \\
\hline & & & High & $1.92 \mathrm{a}$ & $0.47 \mathrm{a}^{b}$ & $1.31 \mathrm{a}^{c}$ & $1.34 \mathrm{~b}$ & $1.95 \mathrm{a}$ & $4.39 \mathrm{a}$ & $0.52 \mathrm{~b}$ & $1.76 \mathrm{~b}$ & $1.81 \mathrm{~b}$ & $2.80 \mathrm{~b}$ & $1.56 \mathrm{~b}$ \\
\hline \multirow[t]{2}{*}{10 Sept. } & \multirow[t]{2}{*}{78} & \multirow[t]{2}{*}{ First } & Control & $1.95 \mathrm{a}$ & $1.30 \mathrm{a}$ & $1.98 \mathrm{a}$ & $1.27 \mathrm{a}$ & $2.78 \mathrm{a}$ & $13.23 \mathrm{a}$ & $0.70 \mathrm{a}$ & $2.35 \mathrm{a}$ & $2.07 \mathrm{a}$ & $3.06 \mathrm{a}$ & $1.58 \mathrm{a}$ \\
\hline & & & High & $1.96 \mathrm{a}$ & $1.27 \mathrm{a}$ & $1.96 \mathrm{a}$ & $1.25 \mathrm{a}$ & $2.77 \mathrm{a}$ & $13.14 \mathrm{a}$ & $0.69 \mathrm{a}$ & $2.31 \mathrm{a}$ & $2.04 \mathrm{a}$ & $3.04 \mathrm{a}$ & $1.54 \mathrm{a}$ \\
\hline \multirow[t]{3}{*}{26 Sept. } & \multirow[t]{3}{*}{94} & \multirow[t]{3}{*}{ First } & Control & $1.69 \mathrm{a}$ & $0.46 \mathrm{a}$ & $0.94 \mathrm{a}$ & $0.65 \mathrm{a}$ & $1.14 \mathrm{a}$ & $-0.80 \mathrm{a}^{d}$ & $0.10 \mathrm{a}$ & $0.63 \mathrm{a}$ & $0.74 a$ & $2.97 \mathrm{a}$ & $0.64 \mathrm{a}$ \\
\hline & & & High & $1.68 \mathrm{a}$ & $0.45 \mathrm{a}$ & $0.91 \mathrm{a}$ & $0.63 \mathrm{a}$ & $1.05 \mathrm{~b}$ & $-1.60 \mathrm{a}^{d}$ & $0.09 \mathrm{a}$ & $0.61 \mathrm{a}$ & $0.72 \mathrm{a}$ & $2.93 \mathrm{~b}$ & $0.64 \mathrm{a}$ \\
\hline & & & or of mean & 0.01 & 0.01 & 0.02 & 0.01 & 0.03 & 0.28 & 0.005 & 0.02 & 0.02 & 0.01 & 0.02 \\
\hline
\end{tabular}

Mean SVI with the same letter within each date are not statistically different at 0.05 level of significance.

${ }^{a} \operatorname{Pr}>\mathrm{t}=0.061$.

${ }^{b} \operatorname{Pr}>\mathrm{t}=0.055$.

${ }^{c} \operatorname{Pr}>\mathrm{t}=0.052$.

${ }^{d} \operatorname{Pr}>\mathrm{t}=0.052$. 
Table 6. Repeated measures analysis of variance of spectral vegetation indices derived from hyperspectral imagery of $O$. nubilalis second generation treated corn plots and noninoculated controls from 2004 and 2005 Iowa

\begin{tabular}{|c|c|c|c|c|c|c|c|c|c|c|c|c|}
\hline \multirow{3}{*}{ Index } & \multicolumn{6}{|c|}{2004 second generation O. nubilalis } & \multicolumn{6}{|c|}{2005 second generation $O$. nubilalis } \\
\hline & \multicolumn{2}{|c|}{$\begin{array}{l}\text { Treatment } \\
(\mathrm{df}=1,4)\end{array}$} & \multicolumn{2}{|c|}{$\begin{array}{c}\text { Time } \\
(\mathrm{df}=3,32)\end{array}$} & \multicolumn{2}{|c|}{$\begin{array}{c}\text { Treatment } \times \text { time } \\
\quad(\mathrm{df}=3,32)\end{array}$} & \multicolumn{2}{|c|}{$\begin{array}{l}\text { Treatment } \\
(\mathrm{df}=2,4)\end{array}$} & \multicolumn{2}{|c|}{$\begin{array}{c}\text { Time } \\
(\mathrm{df}=4,48)\end{array}$} & \multicolumn{2}{|c|}{$\begin{array}{c}\text { Treatment } \times \\
\text { time } \\
(\mathrm{df}=8,48)\end{array}$} \\
\hline & $F$ & $P$ & $F$ & $P$ & $F$ & $P$ & $F$ & $P$ & $F$ & $P$ & $F$ & $P$ \\
\hline ARI & 34.61 & 0.0042 & 2185.55 & $<0.0001$ & 105.62 & $<0.0001$ & 0.69 & 0.5541 & 1191.59 & $<0.0001$ & 2.80 & 0.0124 \\
\hline $\mathrm{CRI}_{\text {green }}$ & 6.62 & 0.0618 & 1550.48 & $<0.0001$ & 31.97 & $<0.0001$ & 9.53 & 0.0301 & 4079.31 & $<0.0001$ & 1.43 & 0.2100 \\
\hline $\mathrm{CRI}_{\text {red }}$ & 58.55 & 0.0016 & 1575.21 & $<0.0001$ & 114.11 & $<0.0001$ & 5.26 & 0.0758 & 2556.71 & $<0.0001$ & 1.09 & 0.3844 \\
\hline GM & 29.25 & 0.0057 & 2240.58 & $<0.0001$ & 115.12 & $<0.0001$ & 17.15 & 0.0109 & 5881.57 & $<0.0001$ & 11.38 & $<0.0001$ \\
\hline MCARI & 47.71 & 0.0023 & 1192.63 & $<0.0001$ & 91.16 & $<0.0001$ & 0.82 & 0.4946 & 6923.21 & $<0.0001$ & 5.47 & $<0.0001$ \\
\hline MOSR & 68.02 & 0.0012 & 743.32 & $<0.0001$ & 80.12 & $<0.0001$ & 1.39 & 0.3482 & 2201.31 & $<0.0001$ & 9.88 & $<0.0001$ \\
\hline NDVI & 18.06 & 0.0132 & 1529.20 & $<0.0001$ & 86.99 & $<0.0001$ & 27.13 & 0.0047 & 18156.8 & $<0.0001$ & 27.50 & $<0.0001$ \\
\hline $\operatorname{PSSR}_{\mathrm{a}}$ & 16.35 & 0.0156 & 1896.52 & $<0.0001$ & 102.45 & $<0.0001$ & 23.00 & 0.0064 & 11767.10 & $<0.0001$ & 14.86 & $<0.0001$ \\
\hline PSSR $_{b}$ & 26.79 & 0.0066 & 1722.84 & $<0.0001$ & 114.74 & $<0.0001$ & 24.40 & 0.0057 & 9969.61 & $<0.0001$ & 18.82 & $<0.0001$ \\
\hline Red edge & 210.83 & 0.0001 & 382.93 & $<0.0001$ & 97.47 & $<0.0001$ & 4.35 & 0.0992 & 259.89 & $<0.0001$ & 2.29 & 0.0367 \\
\hline $\mathrm{RM}$ & 9.83 & 0.0350 & 2008.51 & $<0.0001$ & 89.55 & $<0.0001$ & 23.31 & 0.0062 & 8902.68 & $<0.0001$ & 15.59 & $<0.0001$ \\
\hline
\end{tabular}

50 DAT for the SVI GM, NDVI, PSSR, PSSR $_{\mathrm{b}}$, and RM. $\mathrm{CRI}_{\text {green }}$ was the only nonchlorophyll based SVI of the six but was able to distinguish differences between high $O$. nubilalis treatments and noninoculated controls once, at 50 DAT (Table 8) but was not clearly separable from the low infestation treatment. At 66 DAT, NDVI was the only SVI of the six with detectable differences between high $O$. nubilalis infestation treatments and noninoculated controls. Although MCARI and MOSR both were able to detect differences at 66 DAT among high $O$. nubilalis infestation treatments, low infestation treatments, and noninoculated controls, neither were able to do so earlier.

\section{Discussion}

Our results suggest that it may be possible to use SVI derived from airborne hyperspectral imagery for detection of plant stress caused by $O$. nubilalis larvae feeding within corn stalks. SVI detection of plant stress in our manually inoculated second generation $O$. nubilalis plots seemed to peak 5-6 wk postinoculation (Tables 7 and 8) Although none of the SVI examined in this study detected first generation infestation plots in 2004, positive results for 2005 suggest the possibility of early season detection of $O$. nubilalis damage under certain conditions.
Although damage to corn plants during the vegetative growth stage by first generation $O$. nubilalis stalk tunneling can result in stunted plants with smaller and fewer leaves, foliar feeding by $O$. nubilalis larvae that is characterized by small holes and lesions in the leaf tissue, would likely need to be significant to reduce photosynthetic leaf area sufficiently for detection by an airborne sensor. It is plausible that stalk tunneling by multiple larvae or a combination of stalk tunneling and inadequate water availability during the vegetative growth stage will increase the rate at which a plant senesces, making it possible to detect damage by first generation $O$. nubilalis larvae late in the season using airborne remote sensed imagery. However, it will likely be difficult to consistently detect early season $O$. nubilalis damage every year as evidenced by only a single year of positive results. Furthermore, the rate of plant senescence for plants stressed by $O$. nubilalis feeding would likely be intensified through interaction with other stressors such as drought, disease or additional insect damage.

Based on the positive results for the chlorophyllbased SVI (GM, NDVI, PSSR, PSSR $_{\mathrm{b}}$, and RM) at detecting second generation $O$. nubilalis injury, we propose that the improved spectral and spatial resolution provided by airborne hyperspectral remote sensing is especially effective for detecting changes in

Table 7. Mean spectral vegetation indices for $O$. nubilalis inoculation treatments and noninoculated control by time of image acquisition for second generation $O$. nubilalis inoculated treatments from 2004 Iowa

\begin{tabular}{|c|c|c|c|c|c|c|c|c|c|c|c|c|c|c|}
\hline Date & $\begin{array}{l}\text { Days after } \\
\text { treatment }\end{array}$ & $\begin{array}{l}\text { O. nubilalis } \\
\text { generation }\end{array}$ & Treatment & ARI & $\mathrm{CRI}_{\text {green }}$ & $\mathrm{CRI}_{\text {red }}$ & GM & MCARI & MOSR & NDVI & $\operatorname{PSSR}_{\mathrm{a}}$ & PSSR $_{\mathrm{b}}$ & Red edge & $\mathrm{RM}$ \\
\hline \multirow[t]{2}{*}{9 Aug. } & \multirow[t]{2}{*}{12} & \multirow[t]{2}{*}{ Second } & Control & $1.88 \mathrm{a}$ & $1.56 \mathrm{a}$ & $0.96 \mathrm{a}$ & $1.90 \mathrm{a}$ & $6.04 \mathrm{a}$ & $3.73 \mathrm{a}$ & $0.51 \mathrm{a}$ & $1.61 \mathrm{a}$ & $2.13 \mathrm{a}$ & $2.95 \mathrm{a}$ & $0.95 \mathrm{a}$ \\
\hline & & & High & $1.89 \mathrm{a}$ & $1.55 \mathrm{a}$ & $0.97 \mathrm{a}$ & $1.92 \mathrm{a}$ & $5.95 \mathrm{a}$ & $3.70 \mathrm{a}$ & $0.52 \mathrm{a}$ & $1.65 \mathrm{a}$ & $2.15 \mathrm{a}$ & $2.96 \mathrm{a}$ & $0.98 \mathrm{a}$ \\
\hline \multirow[t]{2}{*}{20 Aug. } & \multirow[t]{2}{*}{23} & \multirow[t]{2}{*}{ Second } & Control & $1.93 \mathrm{a}$ & $1.50 \mathrm{a}$ & $0.97 \mathrm{a}$ & $1.93 \mathrm{a}$ & $6.82 \mathrm{a}$ & $3.95 \mathrm{a}$ & $0.52 \mathrm{a}$ & $1.65 \mathrm{a}$ & $2.13 a$ & $2.93 \mathrm{a}$ & $0.90 \mathrm{a}$ \\
\hline & & & High & $1.92 \mathrm{a}$ & $1.51 \mathrm{a}$ & $0.96 \mathrm{a}$ & $1.91 \mathrm{a}$ & $6.63 \mathrm{a}$ & $3.90 \mathrm{a}$ & $0.51 \mathrm{a}$ & $1.63 \mathrm{a}$ & $2.10 \mathrm{a}$ & $2.93 \mathrm{a}$ & $0.90 \mathrm{a}$ \\
\hline \multirow[t]{2}{*}{3 Sept. } & \multirow[t]{2}{*}{37} & \multirow[t]{2}{*}{ Second } & Control & $1.51 \mathrm{~b}$ & $1.67 \mathrm{a}$ & $0.69 \mathrm{~b}$ & $1.55 \mathrm{~b}$ & $4.92 \mathrm{~b}$ & $3.54 \mathrm{~b}$ & $0.41 b$ & $1.14 \mathrm{~b}$ & $1.60 \mathrm{~b}$ & $2.89 \mathrm{~b}$ & $0.73 \mathrm{a}$ \\
\hline & & & High & $1.23 \mathrm{a}$ & $1.72 \mathrm{~b}$ & $0.39 \mathrm{a}$ & $1.29 \mathrm{a}$ & $2.83 \mathrm{a}$ & $2.78 \mathrm{a}$ & $0.30 \mathrm{a}$ & $0.75 \mathrm{a}$ & $1.04 \mathrm{a}$ & $2.61 \mathrm{a}$ & $0.59 \mathrm{~b}$ \\
\hline \multirow[t]{3}{*}{17 Sept. } & \multirow[t]{3}{*}{51} & \multirow[t]{2}{*}{ Second } & Control & $1.20 \mathrm{~b}$ & $1.74 \mathrm{a}$ & $0.39 \mathrm{~b}$ & $1.22 \mathrm{~b}$ & $2.57 \mathrm{~b}$ & $2.86 \mathrm{~b}$ & $0.24 b$ & $0.55 b$ & $0.79 b$ & $2.74 \mathrm{~b}$ & $0.45 \mathrm{~b}$ \\
\hline & & & High & $1.07 \mathrm{a}$ & $1.73 \mathrm{a}$ & $0.16 \mathrm{a}$ & $1.09 \mathrm{a}$ & $1.47 \mathrm{a}$ & $2.19 \mathrm{a}$ & $0.17 \mathrm{a}$ & $0.37 \mathrm{a}$ & $0.49 \mathrm{a}$ & $2.43 \mathrm{a}$ & $0.38 \mathrm{a}$ \\
\hline & & \multicolumn{2}{|c|}{ SEM } & 0.01 & 0.004 & 0.01 & 0.01 & 0.11 & 0.04 & 0.01 & 0.02 & 0.02 & 0.02 & 0.01 \\
\hline
\end{tabular}


Table 8. Mean spectral vegetation indices for $O$. nubilalis inoculation treatments and noninoculated control by time of image acquisition for second generation $O$. nubilalis inoculated treatments from 2005 Iowa

\begin{tabular}{|c|c|c|c|c|c|c|c|c|c|c|c|c|c|c|}
\hline $\begin{array}{c}\text { Image } \\
\text { acquisition } \\
\text { date }\end{array}$ & $\begin{array}{l}\text { Days after } \\
\text { treatment }\end{array}$ & $\begin{array}{l}\text { O. nubilalis } \\
\text { generation }\end{array}$ & Treatment & ARI & $\mathrm{CRI}_{\text {green }}$ & $\mathrm{CRI}_{\text {red }}$ & GM & MCARI & MOSR & NDVI & $\operatorname{PSSR}_{\mathrm{a}}$ & $\mathrm{PSSR}_{\mathrm{b}}$ & Red edge & $\mathrm{RM}$ \\
\hline \multirow[t]{3}{*}{1 Aug. } & \multirow[t]{3}{*}{10} & \multirow[t]{3}{*}{ Second } & Control & $1.67 \mathrm{a}$ & $1.27 \mathrm{a}$ & $1.40 \mathrm{a}$ & $1.70 \mathrm{a}$ & $2.52 \mathrm{a}$ & $3.78 \mathrm{a}$ & $0.73 \mathrm{a}$ & $2.72 \mathrm{a}$ & $2.51 \mathrm{a}$ & $3.11 \mathrm{a}$ & $2.34 \mathrm{a}$ \\
\hline & & & Low & $1.66 \mathrm{a}$ & $1.27 \mathrm{a}$ & $1.40 \mathrm{a}$ & $1.70 \mathrm{a}$ & $2.50 \mathrm{a}$ & $3.76 \mathrm{a}$ & $0.73 \mathrm{a}$ & $2.72 \mathrm{a}$ & $2.51 \mathrm{a}$ & $3.11 \mathrm{a}$ & $2.35 \mathrm{a}$ \\
\hline & & & High & $1.66 \mathrm{a}$ & $1.26 \mathrm{a}$ & $1.39 \mathrm{a}$ & $1.69 \mathrm{a}$ & $2.54 \mathrm{a}$ & $3.79 \mathrm{a}$ & $0.74 a$ & $2.72 \mathrm{a}$ & $2.51 \mathrm{a}$ & $3.12 \mathrm{a}$ & $2.34 \mathrm{a}$ \\
\hline \multirow[t]{3}{*}{17 Aug. } & \multirow[t]{3}{*}{26} & \multirow[t]{3}{*}{ Second } & Control & $1.61 \mathrm{a}$ & $1.56 \mathrm{a}$ & $1.62 \mathrm{a}$ & $1.60 \mathrm{a}$ & $2.66 \mathrm{a}$ & $3.87 \mathrm{a}$ & $0.74 a$ & $2.67 \mathrm{a}$ & $2.50 \mathrm{a}$ & $2.95 \mathrm{a}$ & $2.26 \mathrm{~b}$ \\
\hline & & & Low & $1.61 \mathrm{a}$ & $1.54 \mathrm{a}$ & $1.61 \mathrm{a}$ & $1.59 \mathrm{a}$ & $2.64 \mathrm{a}$ & $3.86 \mathrm{a}$ & $0.74 a$ & $2.65 \mathrm{a}$ & $2.48 \mathrm{a}$ & $2.94 \mathrm{a}$ & $2.25 \mathrm{~b}$ \\
\hline & & & High & $1.64 \mathrm{a}$ & $1.52 \mathrm{a}$ & $1.60 \mathrm{a}$ & $1.55 \mathrm{a}$ & $2.72 \mathrm{a}$ & $3.92 \mathrm{a}$ & $0.73 \mathrm{a}$ & $2.61 \mathrm{a}$ & $2.45 \mathrm{a}$ & $2.94 \mathrm{a}$ & $2.18 \mathrm{a}$ \\
\hline \multirow[t]{3}{*}{30 Aug. } & \multirow[t]{3}{*}{39} & \multirow[t]{3}{*}{ Second } & Control & $1.91 \mathrm{a}$ & $0.52 \mathrm{a}$ & $1.12 \mathrm{a}$ & $1.40 \mathrm{~b}$ & $2.69 \mathrm{a}$ & $3.97 \mathrm{a}$ & $0.55 \mathrm{~b}$ & $1.99 \mathrm{~b}$ & $2.03 \mathrm{~b}$ & $2.86 \mathrm{~b}$ & $1.63 \mathrm{~b}$ \\
\hline & & & Low & $1.91 \mathrm{a}$ & $0.51 \mathrm{a}$ & $1.11 \mathrm{a}$ & $1.38 \mathrm{~b}$ & $2.66 \mathrm{a}$ & $3.96 \mathrm{a}$ & $0.54 \mathrm{~b}$ & $1.97 \mathrm{~b}$ & $2.00 \mathrm{~b}$ & $2.84 \mathrm{ab}$ & $1.61 \mathrm{~b}$ \\
\hline & & & High & $1.89 \mathrm{a}$ & $0.45 a$ & $1.04 \mathrm{a}$ & $1.27 \mathrm{a}$ & $2.67 \mathrm{a}$ & $4.00 \mathrm{a}$ & $0.47 \mathrm{a}$ & $1.80 \mathrm{a}$ & $1.84 \mathrm{a}$ & $2.77 \mathrm{a}$ & $1.44 \mathrm{a}$ \\
\hline \multirow[t]{3}{*}{10 Sept. } & \multirow[t]{3}{*}{50} & \multirow[t]{3}{*}{ Second } & Control & $1.94 \mathrm{a}$ & $1.30 \mathrm{~b}$ & $1.64 \mathrm{a}$ & $1.27 \mathrm{~b}$ & $4.04 \mathrm{a}$ & $4.96 \mathrm{a}$ & $0.70 \mathrm{~b}$ & $2.44 \mathrm{~b}$ & $2.19 \mathrm{~b}$ & $3.06 \mathrm{a}$ & $1.58 \mathrm{~b}$ \\
\hline & & & Low & $1.94 \mathrm{a}$ & $1.28 \mathrm{ab}$ & $1.62 \mathrm{a}$ & $1.26 \mathrm{~b}$ & $4.03 \mathrm{a}$ & $4.96 \mathrm{a}$ & $0.70 \mathrm{~b}$ & $2.42 \mathrm{~b}$ & $2.18 \mathrm{~b}$ & $3.05 \mathrm{a}$ & $1.56 \mathrm{~b}$ \\
\hline & & & High & $1.93 \mathrm{a}$ & $1.21 \mathrm{a}$ & $1.57 \mathrm{a}$ & $1.19 \mathrm{a}$ & $4.01 \mathrm{a}$ & $4.99 \mathrm{a}$ & $0.66 \mathrm{a}$ & $2.29 \mathrm{a}$ & $2.07 \mathrm{a}$ & 3.01a & $1.43 \mathrm{a}$ \\
\hline \multirow[t]{4}{*}{26 Sept. } & \multirow[t]{4}{*}{66} & \multirow[t]{3}{*}{ Second } & Control & $1.67 \mathrm{a}$ & $0.47 \mathrm{a}$ & $0.75 \mathrm{a}$ & $0.65 \mathrm{a}$ & $1.81 \mathrm{~b}$ & $3.22 \mathrm{~b}$ & $0.10 \mathrm{~b}$ & $1.06 \mathrm{a}$ & $1.13 \mathrm{a}$ & $2.97 \mathrm{a}$ & $0.64 \mathrm{a}$ \\
\hline & & & Low & $1.67 \mathrm{a}$ & $0.46 \mathrm{a}$ & $0.74 a$ & $0.64 \mathrm{a}$ & $1.75 \mathrm{~b}$ & $3.14 \mathrm{~b}$ & $0.09 \mathrm{ab}$ & $1.05 \mathrm{a}$ & $1.12 \mathrm{a}$ & $2.94 \mathrm{a}$ & $0.64 \mathrm{a}$ \\
\hline & & & High & $1.66 \mathrm{a}$ & $0.44 a$ & $0.71 \mathrm{a}$ & $0.60 \mathrm{a}$ & $1.60 \mathrm{a}$ & $2.84 a$ & $0.08 \mathrm{a}$ & $1.01 \mathrm{a}$ & $1.09 \mathrm{a}$ & $2.89 \mathrm{a}$ & $0.60 \mathrm{a}$ \\
\hline & & \multicolumn{2}{|c|}{ SEM } & 0.01 & 0.02 & 0.02 & 0.01 & 0.03 & 0.03 & 0.005 & 0.01 & 0.01 & 0.02 & 0.01 \\
\hline
\end{tabular}

Mean SVI with the same letter within each date are not statistically different at 0.05 level of significance.

chlorophyll content caused by plant stress from feeding O. nubilalis larvae. In contrast, the SVI (ARI, CRI and $\mathrm{CRI}_{\text {red }}$ ) that focused on anthocyanin or carotenoid pigments for detection of $O$. nubilalis feeding stress were not as effective. One likely reason may be that chlorophyll is the primary pigment that determines the amount of light a plant absorbs, and degradation of chlorophyll through catabolism during senescence (Matile and Hortensteiner 1999), or as a result of some other stressor, is an obvious sign of plant health and easily detectable by spectral methods. Plant stress is clearly reflected by changes in chlorophyll concentration, although these changes may be small and may, initially, not be detectable (Blackburn 1998). Until chlorophyll is sufficiently degraded in the leaf, the expression of carotenoid and anthocyanin pigments is masked making detection of either difficult. However, this does not mean anthocyanins and carotenes cannot provide complementary spectral information that may be unique to plants stressed by insect feeding (Blackburn 1998).

Ancillary information, such as spatial heterogeneity of plant pigments, temporal heterogeneity of plant pigment expression and catabolism, canopy structure, and soil type, can provide additional information on individual stressors that may allow insect-related plant stress to be distinguished from nutrient deficiency or disease by remote sensing (GopalaPillai and Tian 1999, Baret et al. 2007, Blackburn 2007). Additionally, spatial heterogeneity of plants exhibiting different plant pigment concentrations over time can help distinguish larger environmental stresses, such as drought, from insect pest or disease stress that initially impact localized areas of a field and may be temporally limited.

This research was conducted on corn plots of same phenology, and were they managed to minimize the physiological response of the plant to other potential stressors, such as nutrient deficiency and weeds. We acknowledge that use of hyperspectral imagery to detect plant stress caused by larval $O$. nubilalis in larger cornfields may be more difficult given the inherent variability of production sized fields especially if there are in-field differences in soil type (Chance 1977, Curran 1985). However, to our knowledge, high spectral and spatial resolution airborne hyperspectral imagery has not been previously used to detect plant stress caused by insect feeding in production corn fields. Unlike imagery acquired by boom mounted or handheld spectroradiometers that are limited by a small FOV and do not typically provide detailed spatial information, airborne hyperspectral imagery is scalable and can provide georeferenced imagery at submeter resolution.

Five of the spectral vegetation indices (GM, NDVI, PSSRa, PSSRb, and RM) used in this study provided consistent, functionally equivalent, results for second generation O. nubilalis in 2004 and 2005. In particular, the NDVI and RM distinguished plots inoculated with second generation $O$. nubilalis more frequently than the other SVI. We suggest that for the purpose of identifying plant stress associated with larval O. nubilalis feeding in transgenic fields that multiple SVI targeting different aspects of the crop be used to avoid overreliance on a single physiological state. Fundamentally, SVI are designed to minimize variation from nondesired factors and maximize sensitivity to a factor of interest (Daughtry et al. 2000). New SVI for corn that may be developed for this purpose should be sensitive to foliage parameters, such as density, but should not be significantly influenced by other factors, such as soil and atmosphere (Gilabert et al. 1996). However, any crop specific SVI would need to be flexible to account for spectral variation among hybrids.

Current demand for corn in the United States has led to significantly higher corn prices and is expected to contribute to increases in planted acreages of transgenic corn. These added plantings increases the possibility of insect pests developing resistance to Bt corn and emphasizes the need for a detection method ca- 
pable of identifying insect related stress in corn. We believe that this study provides evidence that SVI derived from airborne hyperspectral imagery can be used to detect plant stress resulting from larval $O$. nubilalis feeding damage and that this method may provide a means of detecting resistant populations of $O$. nubilalis in production sized Bt corn fields and should be evaluated further.

\section{References Cited}

Alstad, D. N., and D. A. Andow. 1995. Managing the evolution of insect resistance to transgenic plants. Science (Wash., D.C.) 268: 1894-1896.

Alstad, D. N., and D. A. Andow. 1996. Implementing management of insect resistance to transgenic crops. Agbiotech News Info. 8: 177-181.

Apan, A., A. Held, S. Phinn, and J. Markley. 2004. Detecting sugarcane 'orange rust' disease using EO-1 Hyperion hyperspectral imagery. Int J. Remote Sens. 25: 489-498.

Bauer, M. E., J. E. Cipra, P. E. Anuta, and J. B. Etheridge. 1979. Identification and area estimation of agricultural crops by computer classification of LANDSAT MSS data. Remote Sens. Environ. 8: 77-92.

Bauer, M. E. 1985. Spectral inputs to crop identification and condition assessment. Proc. IEEE 73: 1071-1085.

Baret, F., V. Houles, and M. Guerif. 2007. Quantification of plant stress using remote sensing observations and crop models: the case of nitrogen management. J. Exp. Bot. 58: $869-880$

Bergstrom, G. C., and R. L. Nicholson. 1999. The biology of corn anthracnose: knowledge to exploit for improved management. Plant Dis. 83: 596-608.

Blackburn, G. A. 1998. Spectral indices for estimating photosynthetic pigment concentrations: a test using senescent tree leaves. Int. J. Remote Sens. 19: 657-675.

Blackburn, G. A. 2007. Hyperspectral remote sensing of plant pigments. J. Exp. Bot. 58: 855-867.

Blanchfield, A. L., S. A. Robinson, L. J. Renzullo, and K. S. Powell. 2006. Phylloxera-infested grapevines have reduced chlorophyll and increased photoprotective pigment content-can leaf pigment composition aid pest detection. Funct. Plant Biol. 33: 507-514.

Brewster, C. C., J. C. Allen, and D. D. Kopp. 1999. IPM from space: using satellite imagery to construct regional crop maps for studying crop-insect interaction. Am. Entomol. 45: 105-117.

Broge, N. H., and E. Leblanc. 2000. Comparing prediction power and stability of broadband and hyperspectral vegetation indices for estimation of green leaf area index and canopy chlorophyll density. Remote Sens. Environ. 76: $156-172$.

Calera, A., J. Gonzalez-Piqueras, and J. Melia. 2004. Monitoring barley and corn growth from remote sensing data at field scale. Int. J. Remote Sens. 25: 97-109.

Carter, G. A. 1991. Primary and secondary effects of water content on the spectral reflectance of leaves. Am. J. Bot. 78: $916-924$.

Carter, G. A. 1993. Responses of leaf spectral reflectance to plant stress. Am. J. Bot. 80: 239-243.

Chance, J. E. 1977. Applications of suits spectral model to wheat. Remote Sens. Environ. 6: 147-150.

Cihlar, J., L. St.-Laurent, and J. A. Dyer. 1991. Relation between the normalized difference vegetation index and ecological variables. Remote Sens. Environ. 35: 279-298.

Curran, P. J. 1985. Aerial photography for the assessment of crop condition: a review. Appl. Geogr. 5: 347-360.
Daughtry, C.S.T., C. L. Walthall, M. S. Kim, B. Colstoun, and J. E. McMurtrey III. 2000. Estimating corn leaf chlorophyll concentration from leaf and canopy reflectance. Remote Sens. Environ. 74: 229-239.

Diaz-Montano, J., J. C. Reese, W. T. Schapaugh, and L. R. Campbell. 2007. Chlorophyll loss caused by soybean aphid (Hemiptera: Aphididae) feeding on soybean. J. Econ. Entomol. 100: 1657-1662.

Fitzgerald, G. J., S. J. Maas, and W. R. Detar. 2004. Spider mite detection and canopy component mapping in cotton using hyperspectral imagery and spectral mixture analysis. Precision Agric. 5: 275-289.

Gausman, H. W. 1977. Reflectance of leaf components. Remote Sens. Environ 6: 1-9.

Gausman, H. W., and R. Cardenas. 1969. Effect of leaf pubescence of Gynura aurantiaca on light reflectance. Bot. Gaz. 130: 158-162.

Gilabert, M. A., S. Gandia, and J. Melia. 1996. Analyses of spectral-biophysical relationships for a corn canopy. Remote Sens. Environ. 55: 11-20.

Gitelson, A. A., and M. N. Merzlyak. 2004. Non-destructive assessment of chlorophyll, carotenoid and anthocyanin content in higher plant leaves: principles and algorithms, pp. 78-94. In S. Stamatiadis, J. M. Lynch, and J. S. Schepers [eds.], Remote sensing for agriculture and the environment. Peripheral Editions, Larissa, Greece.

Gitelson, A. A., A. Vina, V. Ciganda, D. C. Rundquist, and T. J. Arkebauer. 2005. Remote estimation of canopy chlorophyll content in crops. Geophys. Res. Lett. 32: 8403-8403.

GopalaPillai, S., and L. Tian. 1999. In-field variability detection and spatial yield modeling for corn using digital aerial imagery. Trans. ASAE 42: 1911-1920.

Gould, F. 1998. Sustainability of transgenic insecticidal cultivars: integrating pest genetics and ecology. Annu. Rev. Entomol. 43: 701-726.

Govender, M., K. Chetty, and H. Bulcock. 2007. A review of hyperspectral remote sensing and its application in vegetation and water resource studies. Water SA 33: 145-151.

Grilli, M. P. 2006. Effect of local land use on populations of a disease vector planthopper. Environ. Entomol. 35: 1254-1263.

Guthrie W. D., and B. D. Barry. 1988. Methodologies used for screening and determining resistance in maize to the European corn borer, pp. 122-129. In Toward insect resistant maize for the Third World: Proceedings of the International Symposium on Methodologies for developing host plant resistance to maize insects. CIMMYT, Mexico, D.F. Mexico.

Guyot, G., and F. Baret. 1988. Utilisation de la haute resolution spectral pour suivre l'etat des couverts vegetaux, pp. 279-286. In Proceedings of the fourth international colloquium on spectral signatures of objects in remote sensing. European Space Agency, Aussois, France.

Haboudane, D., J. R. Miller, N. Tremblay, P. J. Zarco-Tejada, and L. Dextraze. 2002. Integrated narrow-band vegetation indices for prediction of crop chlorophyll content for application to precision agriculture. Remote Sens. Environ. 81: 416-426.

Haboudane, D., J. R. Miller, E. Pattey, P. J. Zarco-Tejada, and I. B. Strachan. 2004. Hyperspectral vegetation indices and novel algorithms for predicting green LAI of crop canopies: modeling and validation in the context of precision agriculture. Remote Sens. Environ. 90: 337-352.

Hunt, T. E., L. L. Buschman, and P. E. Sloderbeck. 2007. Insecticide use in $\mathrm{Bt}$ and non-Bt field corn in the western corn belt: as reported by crop consultants in a mail survey. Am. Entomol. 53: 86-93. 
Knipling, E. B. 1970. Physical and physiological basis for the reflectance of visible and near-infrared radiation from vegetation. Remote Sens. Environ. 1: 155-159.

Lichtenthaler, H. K., O. Wenzel, C. Buschmann, and A. A. Gitelson. 1998. Plant stress detection by reflectance and fluorescence. Ann. N Y Acad. Sci. 851: 271-285.

Littell, R. C., G. A. Milliken, W. W. Stroup, and W. D. Russell. 1996. SAS system for mixed models. SAS Institute, Cary, NC.

Matile, P., and S. Hortensteiner. 1999. Chlorophyll degradation. Annu. Rev. Plant Physiol. Plant Mol. Biol. 50: $67-95$.

Mirik, M., G. J. Michels, S. Kassymzhanova-Mirik, N. C. Elliott, and R. Bowling. 2006. Hyperspectral spectrometry as a means to differentiate uninfested and infested winter wheat by greenbug (Hemiptera: Aphididae). J. Econ. Entomol. 99: 1682-1690.

[NASS] United States Department of Agriculture, National Agricultural Statistics Service. 2007a. Crop values 2006 summary. Pr 2 (07): 1-15.

[NASS] United States Department of Agriculture, National Agricultural Statistics Service. 2007b. June 2007 Acreage. Crop production report Cr Pr 2-5 (6-07): 5, 24.

Osborne, S. L., J. S. Schepers, D. D. Francis, and M. R. Schlemmer. 2002. Detection of phosphorus and nitrogen deficiencies in corn using spectral radiance measurements. Agron. J. 94: 1215-1221.

Ostlie, K. R., W. D. Hutchison, and R. L. Hellmich. 1997. Bt-corn and European corn borer: long term success through resistance management, pp. 1-19. North Central Regional Extension Publication NCR 602. University of Minnesota, Minneapolis, MN.

Perry, C.R.J., and L. F. Lautenschlager. 1984. Functional equivalence of spectral vegetation indices. Remote Sens. Environ. 14: 169-182.

Riedell, W. E., and T. M. Blackmer. 1999. Leaf reflectance spectra of cereal aphid-damaged wheat. Crop Sci. 39: $1835-1840$

Reisig, D., and L. Godfrey. 2006. Remote sensing for detection of cotton aphid-(Homoptera: Aphididae) and spider mite-(Acari: Tetranychidae) infested cotton in the San Joaquin valley. Environ. Entomol. 35: 1635-1646.

Ritchie, S. W., J. J. Hanway, and G. O. Benson. 1997. How a corn plant develops. Spec. Publ. 48. Iowa State University Cooperative Extension Service, Ames, IA.

Rouse, J. W., R. H. Haas, J. A. Schell, and D. W. Deering. 1974. Monitoring vegetation systems in the Great Plains with ERTS, pp. 301-317. In Proceedings of the Third Earth Resources Technology Satellite-1 Symposium. NASA, Greenbelt, MD.

Roush, R. T. 1997. Managing resistance to transgenic crops, pp. 271-294. In N. Corozzi and M. Koziel [eds.], Advances in insect control: the role of transgenic plants. Taylor \& Francis, London, United Kingdom.

Schlemmer, M. R., D. D. Francis, J. F. Shanahan, and J. Schepers. 2005. Remotely measuring chlorophyll content in corn leaves with differing nitrogen levels and relative water content. Agron. J. 97: 106-112.

Showers, W. B., H. C. Chiang, A. J. Keaster, R. E. Hill, G. L. Reed, A. N. Sparks, and G. J. Musick. 1975. Ecotypes of the European corn borer in North America. Environ. Entomol. 4: 753-760.

Smith, G. M., and E. J. Milton. 1999. The use of the empirical line method to calibrate remotely sensed data to reflectance. Int. J. Remote Sens. 20: 2653-2662.

Tabashnik, B. E., and B. A. Croft. 1982. Managing pesticide resistance in crop-arthropod complexes: interactions between biological and operational factors. Environ. Entomol. 11: 1137-1144

Thenkabail, P. S., R. B. Smith, and E. De Pauw. 2000. Hyperspectral vegetation indices and their relationships with agricultural crop characteristics. Remote Sens. Environ. 71: 158-182.

Tilling, A. K., G. J. O'Leary, J. G. Ferwerda, S. D. Jones, G. J. Fitzgerald, D. Rodriguez, and R. Belford. 2007. Remote sensing of nitrogen and water stress in wheat. Field Crop Res. 104: 77-85.

Tucker, C. J. 1979. Red and photographic infrared linear combinations for monitoring vegetation. Remote Sens. Environ. 8: 127-150.

[U.S. EPA] United States Environmental Protection Agency, Office of Pesticide Programs, Biopesticides and Pollution Prevention Division. 2001. Bt plant-incorporated protectants October 15, 2001 biopesticides registration action document. U.S. Environmental Protection Agency, Washington, DC.

Vina, A., A. A. Gitelson, D. C. Rundquist, G. Keydan, B. Leavitt, and J. Schepers. 2004. Remote sensing: monitoring maize (Zea mays L.) phenology with remote sensing. Agron. J. 96: 1139-1147.

Woolley, J. T. 1971. Reflectance and transmittance of light by leaves. Plant Physiol. 47: 656-662.

Zhao, D., K. R. Reddy, V. G. Kakani, J. J. Read, and G. A Carter. 2003. Corn (Zea mays L.) growth, leaf pigment concentration, photosynthesis and leaf hyperspectral reflectance properties as affected by nitrogen supply. Plant Soil 257: 205-217.

Zhao, D. H., J. L. Li, and J. G. Qi. 2005. Identification of red and NIR spectral regions and vegetative indices for discrimination of cotton nitrogen stress and growth stage. Comput. Electron. Agric. 48: 155-169.

Received 17 October 2007; accepted 24 July 2008. 